\title{
Comparative Assessment of Cow Manure Vermicompost and NPK Fertilizers and on the Growth and Production of Zinnia (Zinnia elegans) Flower
}

\author{
Shahin Sultana1, Md. Abul Kashem ${ }^{1,2 *}$, Abul Kalam Mohammad Moniruzzaman Mollah1 \\ ${ }^{1}$ Asian University for Women, Chittagong, Bangladesh \\ ${ }^{2}$ Department of Soil Science, Chittagong University, Chittagong, Bangladesh \\ Email: ${ }^{*}$ abul.kashem@auw.edu.bd
}

Received 10 May 2015; accepted 1 September 2015; published 4 September 2015

Copyright (C) 2015 by authors and Scientific Research Publishing Inc.

This work is licensed under the Creative Commons Attribution International License (CC BY). http://creativecommons.org/licenses/by/4.0/

(c) (i) Open Access

\begin{abstract}
A pot experiment was conducted to investigate the comparative effect of cow manure vermicompost and NPK fertilizers on the growth and flower production of Zinnia (Zinnia elegans). An air dried sandy loam soil was mixed with four rates of NPK fertilizer equivalent to 0 (control), 0.5 dose $\left(\mathrm{N}-\mathrm{P}-\mathrm{K}=69-16-35 \mathrm{~kg}^{-h^{-1}}\right), 1$ dose (recommended) $\left(\mathrm{N}-\mathrm{P}-\mathrm{K}=137-32-70 \mathrm{~kg}^{-} \mathrm{ha}^{-1}\right), 2$ doses (N-P-K = 274-64-140 kg.ha-1) and 4 doses (N-P-K = 548-128-280 kg.ha-1) and three rates of vermicompost equivalent to $5 \%, 10 \%, 20 \%$ by oven dry weight. Two plants were grown in each pot. After blooming of flowers, the plants were harvested at 50 days of growth and leaves and stems were separated. The growth parameters (shoot height, root length, leaf number, total number of flower, flower diameter, fresh and dry weight of flower) of Zinnia plant increased by the application of vermicompost and the effect of NPK fertilizer was not found effective. The growth performance was similar between $10 \%$ and $20 \%$ and hence $10 \%$ vermicompost should be taken into consideration when ornamental plants are grown in potting media.
\end{abstract}

\section{Keywords}

Organic Fertilizer, Soil, Rates of Fertilizer, Flower

\section{Introduction}

Vermiculture is basically the science of breeding and raising earthworms. It defines the thrilling potential for

\footnotetext{
${ }^{*}$ Corresponding author.
}

How to cite this paper: Sultana, S., Kashem, M.A. and Mollah, A.K.M.M. (2015) Comparative Assessment of Cow Manure Vermicompost and NPK Fertilizers and on the Growth and Production of Zinnia (Zinnia elegans) Flower. Open Journal of Soil Science, 5, 193-198. http://dx.doi.org/10.4236/ojss.2015.59019 
waste reduction, fertilizer production, as well as an assortment of possible uses for the future [1]. Vermicompost does not have any adverse effect on soil, plant and environment. It improves soil aeration and structure thereby reducing soil compaction. It improves water retention capacity of soil because of its high organic matter content. It also promotes better root growth and nutrient absorption and improves nutrient status of soil, both macro-nutrients and micro-nutrients [2].

Generally, farmers use chemical fertilizers to improve soil fertility and hence increase the yield of their crops. However, the use of chemical fertilizers causes a great impact on the soil quality and the surrounding environment. Vermicomposting is a non-thermophilic and simple biotechnological process of composting, in which certain species of earthworms and microorganisms are used for biological degradation of organic waste [3] [4]. Vermicompost is aerobically decomposed products of organic wastes such as cattle dung and animal droppings, farm and forest wastes, vegetative waste, municipal solid wastes (MSW). However, for this study, cow manure was used as source of vermicompost because it is available in rural areas. Vermicomposting is a low-cost technology, environmentally-friendly process used to treat degradable organic waste. It is a plant nutrient-rich, microbiologically-active organic amendment that results from the interactions between earthworms and microorganisms during the decomposition process of organic waste [5]. Vermicomposting generally converts organic matter to a more uniform size, which gives the final substrate a characteristic earthy appearance, whereas the material resulting from composting usually has a more heterogeneous appearance [6] [7].

This organic fertilizer is therefore increasingly considered in agriculture and horticulture as a promising alternative to chemical fertilizers and/or peat in greenhouse potting media. However, the effects of vermicompost on the growth of horticultural plants are not yet fully understood.

Therefore, the objective of this study was to assess the effect of cow manure vermicompost and NPK Fertilizer on the growth and production of Zinnia (Zinnia elegans) flower.

\section{Materials and Methods}

A pot experiment was carried out in the roof top of a building of Asian University for women in Chittagong, Bangladesh. A sandy loam surface soil $(0-15 \mathrm{~cm})$ was used. Soil sample was air dried and passed through a 4$\mathrm{mm}$ sieve for using the soil in the pots for plant growth experiment. A sub sample was air dried and passed through a 2-mm sieve and stored for laboratory analysis, Soil $\mathrm{pH}$ of 5.1 was measured at 1:2.5 soil to water ratio, soil organic carbon of $0.93 \%$ was measured by Walkley and Black [8] and CEC of $4.01 \mathrm{cmol} \cdot \mathrm{kg}^{-1}$ was measured with $1 \mathrm{M} \mathrm{NH}_{4} \mathrm{OAc}$ extraction [9]. The percentages of sand (73\%), silt (13\%) and clay (14\%) were measured by hydrometer method [10]. The vermicompost used in this research was resulted from processing on the cow manure with the help of Eisenia fetida worms. The $\mathrm{pH}$ of vermicompost was of 7.17 and organic carbon was of $17.8 \%$ measured by ignition method. Other chemical properties ( $\mathrm{N}, \mathrm{K}, \mathrm{Ca}, \mathrm{Mg}, \mathrm{Fe}, \mathrm{Mn}, \mathrm{Zn}$ and $\mathrm{Cu}$ ) in the vermicompost were determined by Atomic Absorption Spectrophotometry (AAS) and P by Flame Photometry after digestion with $\mathrm{H}_{2} \mathrm{O}_{2}-\mathrm{H}_{2} \mathrm{SO}_{4}$ acids mixture [11] (Table 1). Four rates of NPK fertilizers equivalent to 0 (control),

Table 1. Nutrient status of vermicompost used in the experiment.

\begin{tabular}{ccc}
\hline Property & Vermicompost \\
\hline $\mathrm{pH}$ & 7.17 \\
$\mathrm{C}(\%)$ & 17.8 \\
$\mathrm{~N}(\%)$ & 1.78 \\
$\mathrm{P}(\%)$ & 0.77 \\
$\mathrm{~K}(\%)$ & 0.94 \\
$\mathrm{Ca}(\%)$ & 1.5 \\
$\mathrm{Mg}(\%)$ & 0.53 \\
$\mathrm{Fe}(\%)$ & 0.44 \\
$\mathrm{Mn}\left(\mathrm{mg} \cdot \mathrm{kg}^{-1}\right)$ & 180 \\
$\mathrm{Zn}\left(\mathrm{mg} \cdot \mathrm{kg}^{-1}\right)$ & 260 \\
$\mathrm{Cu}\left(\mathrm{mg} \cdot \mathrm{kg}^{-1}\right)$ & 354 \\
\hline
\end{tabular}


0.5 dose (N-P-K = 69-16-35 $\left.\mathrm{kg} \cdot \mathrm{ha}^{-1}\right), 1$ dose (recommended) $\left(\mathrm{N}-\mathrm{P}-\mathrm{K}=137-32-70 \mathrm{~kg} \cdot \mathrm{ha}^{-1}\right), 2$ doses $(\mathrm{N}-\mathrm{P}-\mathrm{K}=$ 274-64-140 $\mathrm{kg} \cdot \mathrm{ha}^{-1}$ ) and 4 doses (N-P-K $=548-128-280 \mathrm{~kg} \cdot \mathrm{ha}^{-1}$ ) and three rates of vermicompost equivalent to $5 \%, 10 \%$, and $20 \%$ by oven dry weight were applied separately in each pot containing five (5) kg soil. The 1 dose (N-P-K $=137-32-70 \mathrm{~kg} \cdot \mathrm{ha}^{-1}$ ) fertilizer rate is consider as normal dose for most crops grown in this soil [12]. The pots were arranged in a completely randomized design (CRD) with three replications. The PK fertilizers were applied in the form of tripple super phosphate (TSP) and murate of potash (MP) during soil preparation prior to transplanting and $\mathrm{N}$ was applied as urea after 15 days of transplanting the Zinnia (Zinnia elegans) plant.

Two seedlings Zinnia of 20 days old were grown in each pot and water was maintained at field capacity. The plants were harvested at 50 days of growth after transplanting and flowers were collected during this growth period. At harvest, growth parameters (shoot height, root length, total leaf number, leaf length, total number of flower, flower diameter, fresh and dry weight of flowers) were recorded. To get dry weight of flowers, the fresh flowers were kept in oven at $60^{\circ} \mathrm{C}$ for 72 hours.

\section{Statistical Analysis}

Microsoft Excel and Minitab program [13] were used for analysis of variance (ANOVA).

\section{Results}

Variance Analysis of data showed that the impact of growth media treated with vermicompost and NPK fertilizers on shoot height, root length, total leaf number, leaf length, total number of flower, flower diameter, fresh and dry weights of flowers were highly significant at 0.1 percent level $(p<0.001)$ (Table 2).

\subsection{Shoot Height}

At 50 days of growth after transplanting, maximum height $(41 \mathrm{~cm})$ of the shoot was related to $20 \%$ vermicompost and minimum height $(15 \mathrm{~cm})$ of the shoot was obtained in the control. The heights of shoots in the various rates of NPK fertilizers varied from $15 \mathrm{~cm}$ to $20 \mathrm{~cm}$ and in the vermicompost treated pots varied from $29 \mathrm{~cm}$ to $41 \mathrm{~cm}$. The impact of NPK fertilizers on the shoot heights of Zinnia plant were found similar with that of control. Shoot heights of plant increased with the rates of vermicompost application but the values obtained in the $10 \%$ and $20 \%$ was not significantly different (Table 3 ).

\subsection{Root Length}

There was a strong positive correlation between the shoot and root heights of Zinnia plant regardless of treatments. The rates of NPK fertilizers and vermicompost on root height showed similar response as did for shoot heights. The heights of roots were between $5 \mathrm{~cm}$ and $7 \mathrm{~cm}$ in the NPK fertilizers treated pots and between $9 \mathrm{~cm}$ and $11 \mathrm{~cm}$ in the vermicompost treated pots (Table 3).

Table 2. Analysis of variance from ANOVA in various parameters.

\begin{tabular}{ll}
\hline Parameters & \multicolumn{1}{c}{ F } \\
Shoot height & $29.99^{*}$ \\
Roots length & $57.62^{*}$ \\
Leaves number & $60.09^{*}$ \\
Leaf length & $45.15^{*}$ \\
Total number of flowers & $101.23^{*}$ \\
Flowers diameter & $37.12^{*}$ \\
Fresh weight of flowers & $56.16^{*}$ \\
Dry weight of flowers & $35.41^{*}$ \\
\hline
\end{tabular}

\footnotetext{
${ }^{*}$ indicates $p<0.001$ level.
} 
Table 3. Effect of vermicompost and inorganic fertilizers on the growth parameters of Zinnia.

\begin{tabular}{ccccccccc}
\hline Treatment & $\begin{array}{c}\text { Shoot } \\
\text { height } \\
(\mathrm{cm})\end{array}$ & $\begin{array}{c}\text { Root } \\
\text { length } \\
(\mathrm{cm})\end{array}$ & $\begin{array}{c}\text { Total leaf } \\
\text { number/plant }\end{array}$ & $\begin{array}{c}\text { Leaf } \\
\text { length } \\
(\mathrm{cm})\end{array}$ & $\begin{array}{c}\text { Total } \\
\text { number of } \\
\text { flowers/plant }\end{array}$ & $\begin{array}{c}\text { Flowers } \\
\text { diameter } \\
(\mathrm{cm})\end{array}$ & $\begin{array}{c}\text { Fresh } \\
\text { weight (g) of } \\
\text { flowers/plant }\end{array}$ & $\begin{array}{c}\text { Dry weight } \\
\text { (g) of } \\
\text { flowers/plant }\end{array}$ \\
\hline 0 (Control) & $14.9 \mathrm{c}$ & $5.1 \mathrm{c}$ & $8 \mathrm{~d}$ & $3.3 \mathrm{c}$ & $1.5 \mathrm{~d}$ & $1.62 \mathrm{~d}$ & $0.09 \mathrm{~d}$ & $0.03 \mathrm{~d}$ \\
0.5 dose NPK & $15.5 \mathrm{c}$ & $5.4 \mathrm{c}$ & $9 \mathrm{~d}$ & $3.9 \mathrm{c}$ & $2.5 \mathrm{c}$ & $1.83 \mathrm{~d}$ & $1.08 \mathrm{c}$ & $0.08 \mathrm{c}$ \\
1 dose NPK & $18.4 \mathrm{c}$ & $6.2 \mathrm{c}$ & $9 \mathrm{~d}$ & $4.4 \mathrm{bc}$ & $2.5 \mathrm{c}$ & $1.96 \mathrm{~cd}$ & $1.35 \mathrm{c}$ & $0.07 \mathrm{c}$ \\
2 doses NPK & $19.7 \mathrm{c}$ & $7.0 \mathrm{c}$ & $10 \mathrm{~d}$ & $5.1 \mathrm{bc}$ & $2.5 \mathrm{c}$ & $2.31 \mathrm{c}$ & $1.38 \mathrm{c}$ & $0.08 \mathrm{c}$ \\
4 doses NPK & $20.5 \mathrm{c}$ & $7.0 \mathrm{c}$ & $14 \mathrm{c}$ & $5.6 \mathrm{~b}$ & $3.0 \mathrm{c}$ & $2.83 \mathrm{c}$ & $1.43 \mathrm{c}$ & $0.13 \mathrm{~b}$ \\
$5 \% \mathrm{VC}$ & $28.7 \mathrm{~b}$ & $9.2 \mathrm{~b}$ & $21 \mathrm{~b}$ & $7.8 \mathrm{a}$ & $4.0 \mathrm{~b}$ & $4.43 \mathrm{a}$ & $1.97 \mathrm{~b}$ & $0.25 \mathrm{a}$ \\
$10 \% \mathrm{VC}$ & $39.8 \mathrm{a}$ & $11.1 \mathrm{a}$ & $29 \mathrm{a}$ & $8.5 \mathrm{a}$ & $6.0 \mathrm{a}$ & $5.13 \mathrm{a}$ & $2.46 \mathrm{a}$ & $0.30 \mathrm{a}$ \\
$20 \% \mathrm{VC}$ & $41.3 \mathrm{a}$ & $11.2 \mathrm{a}$ & $32 \mathrm{a}$ & $9.1 \mathrm{a}$ & $7.0 \mathrm{a}$ & $5.61 \mathrm{a}$ & $2.65 \mathrm{a}$ & $0.27 \mathrm{a}$ \\
\hline
\end{tabular}

Means followed by the same letter(s) in a column is not significantly different at $p<0.01$ level. VC denotes vermicompost.

\subsection{Number of Leaf}

Total number of leaf per plant varied from 8 in the control to 32 in the $20 \%$ in the vermicompost treated pot. The influence of NPK fertilizers and vermicompost on number of leaf production was found similar as was observed for shoot height and root length. Vermicompost produced four and three folds higher leaf number compare to control and NPK fertilizers, respectively (Table 3).

\subsection{Leaf Length}

The length of leaf increased slightly from 3.3 to $5.6 \mathrm{~cm}$ with the rates of NPK fertilizer and from $7.8 \mathrm{~cm}$ to 9.1 $\mathrm{cm}$ with vermicompost applications in the growth media. The results showed that the rate effects within NPK fertilizers and vermicompost treatments were not found significant; however, the best performance was recorded in the plants grown with $20 \%$ vermicompost (Table 3 ).

\subsection{Total Number of Flower}

The data of Table 3 showed that total number of flowers per plant was of 1.5 in the control, 2.5 to 3.0 with NPK fertilizers and 4 to 7 in the vermicompost treated pots. The rate effect of NPK fertilizers was not found significant in the production of flowers but it increased with rates of vermicompost application significantly from $5 \%$ to $10 \%$. The rate effect was not significant between $10 \%$ and $20 \%$ vermicompost applied in the growth media (Table 3). We also observed that zinnia plants flowered earlier when grown in vermicomposts amended soil pots compared to those grown in NPK fertilizer treated media.

\subsection{Flowers Diameter}

The average diameter flower was the lowest of $1.6 \mathrm{~cm}$ in the control and the height of $5.33 \mathrm{~cm}$ in the plants grown in $20 \%$ vermicompost application pot. Flowers diameter increased with the rates of NPK fertilizers gradually from 1.8 to $2.3 \mathrm{~cm}$ and from 4.3 to $5.3 \mathrm{~cm}$ with the rates of vermicompost application in the growth media (Figure 1).

\subsection{Fresh and Dry Weight of Flower}

Flowers diameter reflected the fresh and dry weights of flowers irrespective of amendments. These three (Diameter, fresh and dry weights flowers) parameters of flowers were strongly and positively correlated with each other. Like other growth parameters of Zinnia plant, the lowest fresh $(0.09 \mathrm{~g})$ and dry weights $(0.03 \mathrm{~g})$ of flowers obtained in the control pot and highest fresh ( $2.65 \mathrm{~g})$ and dry weights $(0.27 \mathrm{~g})$ was in the $20 \%$ vermicompost treated pots (Table 3, Figure 1). 


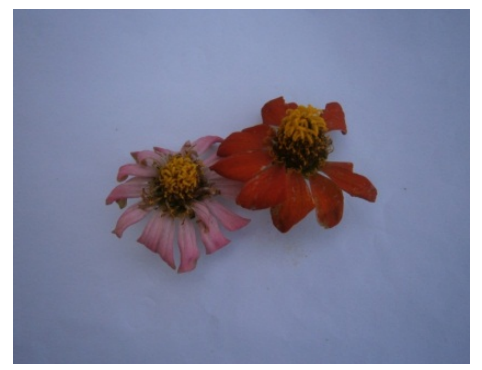

$5 \%$ vermicompost

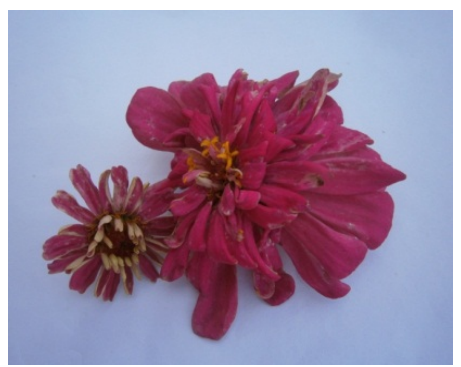

$10 \%$ vermicompost

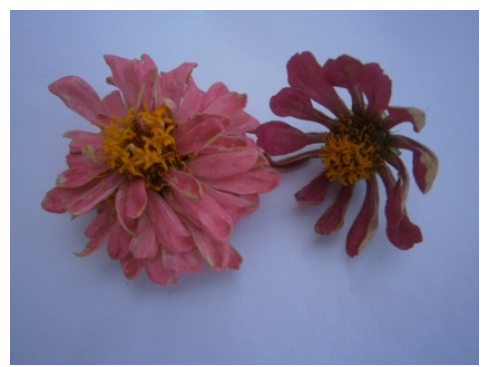

$20 \%$ vermicompost

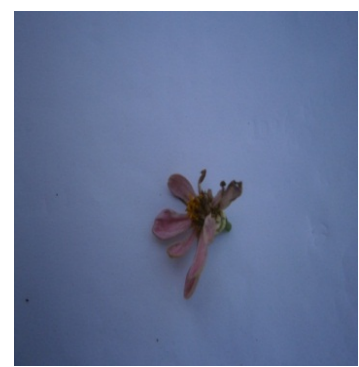

0.5 dose NPK fertilizer

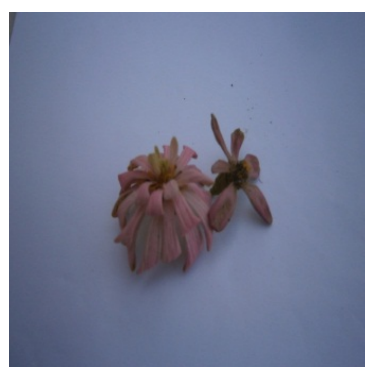

1 dose (Normal) NPK fertilizer

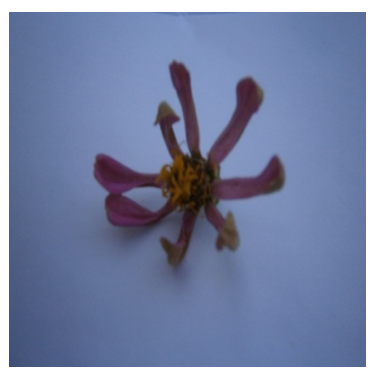

2 doses NPK fertilizer

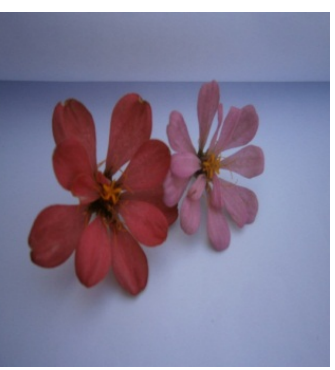

4 doses NPK fertilizer

Figure 1. The effect of NPK fertilizers and vermicompost on Zinnia flower.

\section{Discussion}

The response of Zinnia plant growth and flower production to vermicompost showed much better results compare to NPK fertilizers. The NPK fertilizers were not effective to enhance flower production of Zinnia plants and their rate effects were not also noticeable (Table 3). Similar our results, Edwards and Burrows [14] found that some ornamental plants such as Eleagnus pungens, Cotoneaster conspicua, Pyracantha, Viburnum bodnantense, Chaemaecyparis lawsonia, Cupressocyparis leylandii and Juniperus communis grew better in vermicomposts amended soil than in a commercial plant growth medium. They also reported that chrysanthemums, salvias and petunias plants flowered earlier in vermicomposts compared to those grown in a commercial planting media. In our experiment, Zinnia grew better at $10 \%$ vrmicompost amended soil and $20 \%$ vermicompost did not show any significant result. Wilson and Carlile [15] were reported to be best at substitution into soils at rates of $8 \%-10 \%$ vermicompost for the growth of tomatoes, lettuces, and peppers. Zinnia plants produced big size of flowers in the vermicompost treated pots which is an important indicator of landscape. Our results corroborate with the findings of Shandanpour et al. [16], they studied the effect of cow manure vermicompost as the planting medium on the growth marigold.

Vermicompost can improve physical, chemical and biological and processes of soil which have their bearings on plant's growth. Goutam et al. [17] found that only organic fertilizer treated tomato plants showed more branching than inorganic fertilizer treated plants. It is assured that other factors, such as the presence of beneficial microorganisms or biologically active plant growth influencing substances such as phytohormone are released by beneficial microorganisms present in the vermicompost amended soil [18] [19]. Increased root biomass, enhanced plant growth and development of plant morphology are among the most frequently claimed effects of vermicompost treatment [20]. Researchers of various disciplines agree that plant growth and development are strictly dependent on biological fertility factors. Earthworms stimulate microbial activities and metabolism and also influence microbial populations. As a consequence more available nutrients and microbial metabolites are released into the soil and hence promote plant growth [20].

\section{Conclusion}

To avoid the negative impacts on soil, plant growth and surrounding environment, the uses of vermicompost needs to be increased as they are cheap, production sources are available, organic, reduce the pool of waste from our environment and keep our environment clean and healthy. Vermicompost plays an important role for improving soil physical and chemical properties and hence promote plant growth. For growing ornamental plants, 
the use of vermicompost should be given priority instead of inorganic fertilizer and the rate of vermicompost $10 \%$ should be taken into consideration.

\section{References}

[1] Entre Pinoys (2012) Vermiculture, the Management of Worms. http://www.mixph.com/2006/12/vermiculture-themanagement-of worms.html

[2] Lazcano, C. and Dominguez, J. (2010) Effects of Vermicompost as a Potting Amendment of Two CommerciallyGrown Ornamental Plant Species. Spanish Journal of Agricultural Research, 8, 1260-1270. http://dx.doi.org/10.5424/sjar/2010084-1412

[3] Khan, A. and Fouzia, I. (2011) Chemical Nutrient Analysis of Different Composts (Vermicompost and Pitcompost) and Their Effect on the Growth of a Vegetative Crop Pisum sativum. Asian Journal of Plant Science and Research, 1, 116-130.

[4] Arancon, N.Q. and Edwards, C.A. (2005) Effects of Vermicomposts on Plant Growth. Soil Ecology Laboratory, The Ohio State University, Columbus.

[5] Dominguez, J. (2004) State-of-the-Art and New Perspectives on Vermicomposting Research. In: Edwards. C.A., Ed., Earthworm Ecology, CRC Press LLC, Boca Raton, 401-424. http://dx.doi.org/10.1201/9781420039719.ch20

[6] Ndegwa, P.M. and Thompson, S.A. (2001) Integrating Composting and Vermicomposting in the Treatment and Bioconversion of Biosolids. Bioresource Technology, 76, 107-112. http://dx.doi.org/10.1016/S0960-8524(00)00104-8

[7] Tognetti, C., Laos, F., Mazzarino, M.J. and Hernández, M.T. (2005) Composting vs. Vermicomposting: A Comparison of End Product Quality. Compost Science and Utilization, 13, 6-13. http://dx.doi.org/10.1080/1065657X.2005.10702212

[8] Walkley, A. and Black, I.A. (1934) An Examination of Degtja-Reff Method for Determining Soil Organic Matter and a Proposed Modification of the Chromic Acid Titration Method. Soil Science, 37, 29-38. http://dx.doi.org/10.1097/00010694-193401000-00003

[9] Soil Survey Laboratory Staff (1992) Soil Survey Laboratory Methods Manual. Soil Survey Investigation. Report 42, USDA-SCS, Washington DC.

[10] Bouyoucos, G.J. (1962) Hydrometer Method Improved for Making Particle Size Analysis of Soils. Agronomy Journal, 54, 464-465. http://dx.doi.org/10.2134/agronj1962.00021962005400050028x

[11] Akinremi, O.O., Amisen, N., Kashem, M.A. and Janzen, H.H. (2003) Evaluation of Analytical Methods for Total Phosphorus in Organic Amendments. Communications in Soil Science and Plant Analysis, 34, 2981-2991. http://dx.doi.org/10.1081/CSS-120025220

[12] Soil Resources Development Institute (SRDI) (2005) Upazila Land and Soil Resource Utilization Guide. Chittagong, Bangladesh.

[13] Minitab Inc. (1996) Minitab User Guide Release 11. Minitab, State College.

[14] Edwards, C.A. and Burrows, I. (1988) The Potential of Earthworm Composts as Plant Growth Media. In: Edwards, C.A. and Neuhauser, E.F., Eds., Earthworms in Waste and Environmental Management, SPB Academic Publishing, The Hague, 211-219.

[15] Wilson, D.P. and Carlile, W.R. (1989) Plant Growth in Potting Media Containing Worm-Worked Duck Waste. Acta Horticulture, 238, 205-220. http://dx.doi.org/10.17660/actahortic.1989.238.24

[16] Shadanpour, F., Mohammadi, T.A. and Hashemi, M.K. (2011) The Effect of Cow Manure Vermicompost as the Planting Medium on the Growth of Marigold. Annals of Biological Research, 2, 109-115.

[17] Goutam, K.C., Goutam Bhunia, B. and Susanta, K. (2011) The Effect of Vermicompost and Other Fertilizers on Cultivation of Tomato Plants. Journal of Horticulture and Forestry, 3, 42-45.

[18] Tomati, U. and Galli, E. (1995) Earthworms, Soil Fertility and Plant Productivity. Proceedings of the International Colloquium on Soil Zoology. Acta Zoologica Fennica, 196, 11-14.

[19] Edwards, C.A. (1988) Breakdown of Animal, Vegetable and Industrial Organic Wastes by Earthworms. In: Edwards, C.A. and Neuhauser, E.F., Eds., Earthworms in Waste and Environmental Management, SPB Academic Publishing, The Hague, 21-31.

[20] Tomati, U., Grappelli, A. and Galli, E. (1988) The Hormone-Like Effect of Earthworm Casts on Plant Growth. Biology and Fertility of Soils, 5, 288-294. http://dx.doi.org/10.1007/BF00262133 